This item was submitted to Loughborough's Research Repository by the author.

Items in Figshare are protected by copyright, with all rights reserved, unless otherwise indicated.

\title{
Reshaping relational scripts? Marriage and civil partnership proposals among same-gender couples
}

PLEASE CITE THE PUBLISHED VERSION

PUBLISHER

Taylor \& Francis (Routledge)

\section{VERSION}

AM (Accepted Manuscript)

\section{PUBLISHER STATEMENT}

This is an Accepted Manuscript of an article published by Taylor \& Francis in Psychology and Sexuality on 13 August 2019, available online: http://www.tandfonline.com/10.1080/19419899.2019.1645726.

\section{LICENCE}

CC BY-NC-ND 4.0

\section{REPOSITORY RECORD}

Jowett, Adam, and Elizabeth Peel. 2019. "Reshaping Relational Scripts? Marriage and Civil Partnership Proposals Among Same-gender Couples”. figshare. https://hdl.handle.net/2134/9541949.v1. 
Jowett, A. \& Peel, E. (2019). Reshaping relational scripts? Marriage and civil partnership proposals among same-gender couples. Psychology \& Sexuality http://dx.doi.org/10.1080/19419899.2019.1645726 Please cite published version.

\title{
Reshaping relational scripts? Marriage and civil partnership proposals
}

\section{among same-gender couples}

\author{
Adam Jowett is Assistant Professor in Psychology, School of Psychological, Social and Behavioural \\ Sciences, Coventry University, and Chair of the BPS Psychology of Sexualities Section. \\ Elizabeth Peel is Professor of Communication and Social Interaction, and Associate Pro Vice \\ Chancellor (Doctoral College), Loughborough University.
}

\begin{abstract}
The traditional marriage initiation script entails male partners 'proposing' to female partners. However, little is known about how same-gender couples initiate a marriage or civil partnership. Drawing on qualitative survey data from 82 people in a UK civil partnership or same-gender marriage we identify two marriage initiation themes which foreground the reshaping of script norms for marriage proposals. The first theme, "queer proposals" entails an adaptation of the conventional script. The second theme "jointly negotiated initiations", foregrounds a fundamental departure from heteronormative scripts for initiating the legal formalisation of a relationship. It is argued that the non-normative status of such partnerships not only allow for alternative scripts to socially emerge, but offer a reconceptualization of a cultural script grounded in heteronormative relationship practices. The study therefore makes an important contribution to our understanding of same-gender relationship practices and has significant implications for sexual script theory.
\end{abstract}

Keywords: civil partnership; heteronormativity; same-sex marriage; marriage proposal; engagement; lesbian; gay; same-gender relationship; legal relationship recognition; sexual script theory 
Jowett, A. \& Peel, E. (2019). Reshaping relational scripts? Marriage and civil partnership proposals among same-gender couples. Psychology \& Sexuality http://dx.doi.org/10.1080/19419899.2019.1645726

Please cite published version.

\section{Introduction}

In Western culture the marriage proposal is a highly scripted, gendered and heteronormative relationship ritual. Tradition dictates that men are expected to play the active role of initiating the proposal, while women are expected to adopt a passive and reactive role (Schweingruber, Anahita \& Berns, 2004). Although in some European countries - such as Finland and Ireland - there is the custom that women are permitted to propose during a leap year, this is the exception that proves the cultural rule.

The marriage proposal, as a social practice, can be thought of as being guided by a familiar cultural 'script'. A script refers to a set of actions defined by cultural norms that serve to guide what behaviour should occur in a specific situation (Gagnon \& Simon, 1973). As Simon and Gagnon (1986) state these are 'the instructional guides that exist at the level of collective life. All institutions and institutionalized arrangements can be seen as systems of signs and symbols through which the requirements and the practice of specific roles are given' (p. 98). The convention surrounding the marriage proposal is an example of a social script based on gender roles.

Drawing on interviews with engaged heterosexual couples, Schweingruber, Anahita and Berns (2004) observed five key elements of the marriage proposal script: (1) the man asking the woman to marry him; (2) the man presenting the woman with a ring; (3) the man orchestrating the proposal as a 'surprise'; (4) the man getting down on one knee and; (5) the man asking permission of the woman's father. The first three were found in every proposal described by their heterosexual participants, with the fourth and fifth elements found within the majority of cases. Furthermore, the participants expressed that men were expected to perform this script in a way deemed to be suitably 'romantic'. 
Jowett, A. \& Peel, E. (2019). Reshaping relational scripts? Marriage and civil partnership proposals among same-gender couples. Psychology \& Sexuality http://dx.doi.org/10.1080/19419899.2019.1645726 Please cite published version. Of course, deviation from the script does occur within heterosexual relationships. However, according to the little research available on this topic, only a very small minority of women propose to their male partners and many suggest that they cannot even contemplate any alternative to the traditional script (Schweingruber et al., 2004). Heterosexual men and women consistently report finding the idea of women proposing to be amusing or a sign of desperation, and in some cases where women do propose, the proposal is repeated by the male partner before the engagement is made public (Baker \& Elizabeth, 2013; Lamont, 2013; Sassler \& Miller, 2011). However, research also suggests that women may play a more active role in initiating marriage proposals than would appear from the culturally familiar 'script'. In many cases, heterosexual women prompt their male partners through initiating conversations about the future of their relationship and the proposal only occurs after the couple have reached a mutual understanding that they will marry (Lamont, 2013; Sassler \& Miller, 2011; Schweingruber et al., 2004).

Schweingruber et al. (2004) suggest that in addition to communicating to one's partner a desire to marry, an important function of the marriage proposal is to communicate to family, friends and others something about the quality of the couple's relationship. As such, the proposal story, they suggest, is central to the couple's impression management, and deviating from the script may result in others casting doubt on the significance and potential endurance of the relationship. Indeed, Schweingruber, Cast and Anahita (2008) found that American undergraduate students evaluated hypothetical relationships as stronger when they conformed to a traditional proposal script (i.e. their proposal contained the key elements previously described).

To date, most research on relational scripts has focused on heterosexual respondents, while research on lesbian and gay men's relational scripts has been conspicuously rare (Wiederman, 2015). With marriage and other forms of civil union/partnership increasingly 
Jowett, A. \& Peel, E. (2019). Reshaping relational scripts? Marriage and civil partnership proposals among same-gender couples. Psychology \& Sexuality http://dx.doi.org/10.1080/19419899.2019.1645726

Please cite published version.

available in many Western countries for same-gender couples to legally formalise their relationships, this raises the question of how, or indeed whether, same-gender partners adopt the marriage proposal script. While the roles are clearly laid out for the heterosexual marriage proposal, we know comparatively little about what happens when these 'off-the-shelf' roles are not available (Clarke et al., 2005: 356).

\section{Same-gender courtship scripts}

Until recently same-gender couples have not had access to marriage or marriage-like legal frameworks, and as such little is known about how same-gender couples initiate a marriage. Although some same-gender couples adopted marriage conventions prior to legal frameworks being available, for example in the form of unofficial commitment ceremonies, most research to-date has examined the dating and sexual scripts of lesbians and gay men, rather than scripts surrounding the legal formalising of the relationship (Klinkenberg \& Rose, 1994; Rose, 1996). It is generally suggested that as lesbians and gay men are socialised within a culture where heterosexuality is the norm, there are less well-defined cultural scripts for same-gender courtship and as such lesbians and gay men draw upon the scripts that guide heterosexual dating to some extent (Klinkenberg \& Rose, 1994; Rose, 1996). For instance, scripts for a first date among young heterosexual, lesbian and gay adults have been found to be similar, suggesting that they conform to similar cultural norms at least in the early stages of a relationship (Klinkenberg \& Rose, 1994; Rose \& Frieze, 1993). Others, meanwhile, suggest that lesbians and gay men can be understood to be 'bicultural' because they are socialised and operate within both mainstream (heteronormative) culture and a lesbian and gay (sub)culture which may allow for alternative scripts to emerge (Lukes \& Land, 1990). In their study of lesbian dating, Rose and Zand (2002) found that only a minority of lesbian women consistently performed the role of the initiator or the non-initiator. The 
Jowett, A. \& Peel, E. (2019). Reshaping relational scripts? Marriage and civil partnership proposals among same-gender couples. Psychology \& Sexuality http://dx.doi.org/10.1080/19419899.2019.1645726 Please cite published version. majority rejected traditional gender roles by mutually negotiating or switching roles. They concluded that most lesbians do not adopt active versus reactive roles in dating, and that freedom from gender roles contributed to a more egalitarian approach to dating. Such findings are also replicated more generally within the wider literature on same-gender relationships which suggests that same-gender couples view themselves as having, and appear to achieve, greater equality within their relationships (Dunne, 1997; Kurdek, 2007).

Most research on same-gender marriage rituals has focused on commitment ceremonies and explored the ways that such ceremonies conform to or resist the conventional script for heterosexual weddings (e.g. Clarke, Burgoyne \& Burns, 2013; Kimport, 2012; Lewin, 1998; Smart, 2008; Reczek, Elliott \& Umberson, 2009). Much of this work has found that the traditional heterosexual wedding script typically forms the basis for same-gender ceremonies, but that many deliberately avoid copying traditional wedding conventions entirely. For example, Clarke et al. (2013) found that their participants 'valued the freedom and creativity that comes from living outside the heterosexual norm and many sought ways to affirm their relationships without adhering to traditional heterosexual standards' (p.413).

There is very little research that has examined how same-gender couples initiate a civil partnership or marriage. This aspect was examined by Heaphy, Smart and Einarsdottir (2015) in their interviews with 50 same-gender couples within a civil partnership prior to marriage equality. They found that 'the proposal' featured in many of their participants' civil partnership narratives and distinguished between two types of proposal found in their data: the 'surprise' proposal and the 'prenegotiated' proposal where the couples had already signalled their willingness to formalise the relationship prior to the proposal itself. They also note that some of their participants narrated the proposal with some ambivalence. The current study is the first of its kind to interrogate same-gender proposals through the lens of 
Jowett, A. \& Peel, E. (2019). Reshaping relational scripts? Marriage and civil partnership proposals among same-gender couples. Psychology \& Sexuality http://dx.doi.org/10.1080/19419899.2019.1645726

Please cite published version. sexual script theory, and the first in the UK in the context of equal marriage as opposed to 'marriage-like' legal frameworks.

\section{The context of the current study}

Equal marriage is currently available in 28 countries globally (Ellis, Riggs, Peel, 2020). In the UK, legal recognition of same-gender relationships was first introduced in the form of civil partnerships in 2005. Unlike some forms of 'civil union' in other countries, from the beginning there were few significant legal differences between civil partnership and marriage (Barker \& Monk, 2015). When civil partnerships were introduced, the UK Government insisted that civil partnership was not 'marriage' but provided equivalent legal protections for same-gender couples. The media however largely reported civil partnership as 'marriage in all but name' (Jowett \& Peel, 2010) and many same-gender couples referred to it as such (Heaphy, 2015, 2017; Jowett \& Peel, 2017).

Since 2014 same-gender couples have been able to marry in England, Wales and Scotland. Subsequently, same-gender couples wanting to legally formalise their relationship can choose between civil partnership or marriage. Furthermore, those who had already formed a civil partnership can 'convert' their civil partnership to a marriage. Following the introduction of marriage for same-gender couples, there has been a significant fall in the number of civil partnership formations with 890 civil partnerships formed in 2016 in England and Wales, compared to an annual average of 6,305 between 2007 and 2013 (Government Equalities Office, 2018). At the time of writing, mixed-gender couples can only marry, however after a recent successful legal challenge, legislation to allow mixed-gender civil partnerships is currently making its way through Parliament (BBC News, 2018).

This fall in civil partnership formations since legalising same-sex marriage corresponds with research suggesting greater support for same-sex marriage than for civil 
Jowett, A. \& Peel, E. (2019). Reshaping relational scripts? Marriage and civil partnership proposals among same-gender couples. Psychology \& Sexuality http://dx.doi.org/10.1080/19419899.2019.1645726 Please cite published version. partnerships among lesbians and gay men (Harding \& Peel, 2006). However, in-depth qualitative studies suggest that whilst lesbians and gay men support legal equality, some are ambivalent about marriage and view it as a heteronormative institution (i.e. based on traditional norms associated with heterosexual marriage) which does not reflect their own relationship values (Clarke, Burgoyne, \& Burns, 2006; Harding, 2008). For people who hold this view, civil partnership is understood more in terms of the legal protections it offers. Jowett and Peel (2017) used a qualitative survey to examine how those in a civil partnership or marriage view legal recognition of their relationships within the more recent context of marriage equality. They found that same-gender couples who had converted a civil partnership to a marriage tended to have considered their civil partnership as a marriage from the beginning and treated it as such. Meanwhile many of those who had chosen not to convert to marriage, as well as the few who had entered into a civil partnership after marriage was an option, viewed civil partnership as a modern form of relationship recognition free from the cultural 'baggage' of marriage. In this paper, we explore whether and how same-gender couples engage with marriage proposal rituals, and what alternative scripts are emerging in a rapidly changing social and legal landscape for same-gender couples.

\section{Method}

\section{Design}

The data examined in this article were collected as part of a larger project on the meanings and experiences of civil partnership and same-gender marriage (see also Jowett \& Peel, 2017). Data were collected using a qualitative online survey, which is acknowledged to be an proven method for 'generat[ing] rich, detailed and varied data' (Terry \& Braun, 2017: 17). This was the case for this study, wherein respondents largely wrote detailed narratives about their relationships, and views about civil partnership in the contemporary context of equal 
Jowett, A. \& Peel, E. (2019). Reshaping relational scripts? Marriage and civil partnership proposals among same-gender couples. Psychology \& Sexuality http://dx.doi.org/10.1080/19419899.2019.1645726 Please cite published version. marriage. With respect to our data focused around marriage initiation, the average length of accounts was 104 words (range 6 - 597 words). Qualitative surveys provide a 'wide-angle' lens where the size and breadth of the sample allows the researcher to examine variation within responses (Terry \& Braun, 2017). Online qualitative surveys also provide a robust method for gaining wider access to participants with comparative speed and ease. Bristol Online Surveys (now called Jisc Online Surveys) was the hosting platform for the openended questions, and it was piloted and refined before going 'live'. Our analysis primarily explores responses to questions focused on introductory information about respondents' coupled relationships (e.g. 'Can you tell us a bit about your relationship?'), how respondents met their partners and whether and how a proposal took place. The specific wording of the question in this area was 'Did one of you propose, and if so, how?' which, deliberately foregrounded the (hetero)normative script of marriage being formally initiated by one party. The rationale for designing the question regarding initiation in this way was to 'prompt' production of conventional scripts or accounts of how they deviated from them. 
Jowett, A. \& Peel, E. (2019). Reshaping relational scripts? Marriage and civil partnership proposals among same-gender couples. Psychology \& Sexuality http://dx.doi.org/10.1080/19419899.2019.1645726

\section{Participants}

Please cite published version.

Eighty-two respondents who had formed either in a civil partnership or a same-gender marriage within the UK completed the survey. Of these, $56 \%(n=46)$ were currently married, and $44 \%(n=36)$ were currently in a civil partnership. The majority of respondents $(88 \%, \mathrm{n}=72)$ had originally formed a civil partnership. Of these, half $(50 \%, \mathrm{n}=36)$ converted their civil partnership to a marriage when this became possible. The sample thus comprised of $12 \%(n=10)$ who married after March $2014,44 \%(n=36)$ who had initially registered a civil partnership and subsequently converted to marriage and $44 \%(n=36)$ who were in a civil partnership at the time of the survey. The opportunistic sample consisted predominantly of white, middle-class, able-bodied, women. Further details about participants are provided in Table 1.

Table 1: Sample Characteristics.

\begin{tabular}{|c|c|}
\hline $\begin{array}{l}\text { Sample } \\
\text { Characteristics }\end{array}$ & Sample composition \\
\hline Gender & 74\% (61) Female, 22\% (18) Male, 1\% (1) Trans Female, 2\% (2) Non-binary \\
\hline Sexuality & 59\% (48) Lesbian, 28\% (23) Gay, 10\% (8) Bisexual, 3\% (3) Other (queer and pansexual) \\
\hline Age & Average age 44 (range 25-71), partners' average age 45 (range 25-80) \\
\hline Ethnicity & $\begin{array}{l}\text { All respondents were 'White' or Caucasian apart from one 'White/Asian'. Their partners } \\
\text { were also predominantly white. }\end{array}$ \\
\hline Disability & $96 \%$ (79) were able-boded, 4\% (3) were disabled \\
\hline Class & $\begin{array}{l}70 \%(57) \text { described themselves as 'middle class', 17\% (14) as 'working class'. Remainder } \\
\text { did not answer. }\end{array}$ \\
\hline
\end{tabular}


Jowett, A. \& Peel, E. (2019). Reshaping relational scripts? Marriage and civil partnership proposals among same-gender couples. Psychology \& Sexuality http://dx.doi.org/10.1080/19419899.2019.1645726

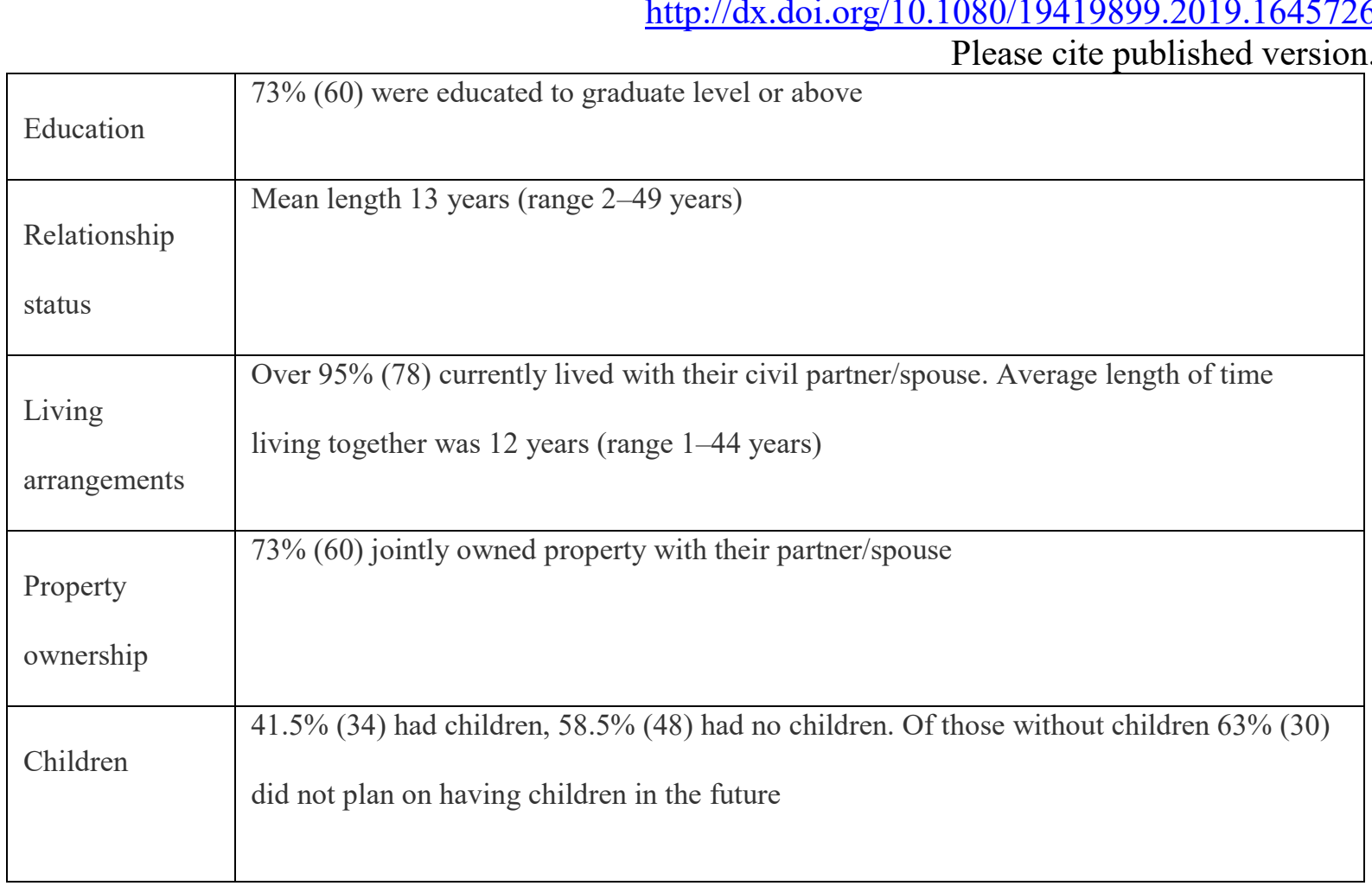

\section{Procedure}

Ethical approval was gained from both of the authors' institutional ethics committees prior to data collection and the survey was live for six months (October 2015-April 2016).

Respondents first encountered an information page where they were informed about the nature of the study and were made aware of how to retrospectively withdraw their data. Respondents were required to indicate their informed consent before proceeding to the survey questions. The inclusion criteria for participation was that the respondents should have formed a civil partnership or same-gender marriage within the UK. No incentives were provided for taking part in the study. A link to the survey was circulated in the following ways: emails were sent to LGBT email lists and organisations; the first author was interviewed by three local radio stations during which listeners were directed to a memorable URL, and; via social media (Twitter and Facebook). Most responses were received in the week following the UK's leading lesbian magazine sharing the link via Twitter, which may explain the gender bias in the sample. 
Jowett, A. \& Peel, E. (2019). Reshaping relational scripts? Marriage and civil partnership proposals among same-gender couples. Psychology \& Sexuality http://dx.doi.org/10.1080/19419899.2019.1645726

Please cite published version.

\section{Analytic method}

Data were analysed using a thorough and well-delineated six-step approach to thematic analysis (Clarke, Braun, \& Hayfield, 2015). Our analysis was conducted within a critical realist framework (Willig, 1999), treating participant responses as more or less 'factual' accounts of what happened, whilst acknowledging that accounts always do more than simply reflect what happens in the real world. As Schweingruber et al. (2004) argue, proposal stories are designedly a narrative aimed to communicate something about the couple's relationship to its audience. Due to the method of data collection the immediate audience - the researchers - were not co-present yet this does not preclude issues of self- and relationship presentation permeating written responses. We draw upon script theory (Simon \& Gagnon, 1986) as a heuristic for conceptualising patterned ways of initiating a marriage or a civil partnership. After an initial phase of data familiarisation (step 1), the first author identified and collated all data relevant to the initiation of the civil partnership or marriage. These data were then coded inductively, identifying features relating to how civil partnership or marriage was initiated (step 2). From this, two themes were identified (step 3) which were reviewed to ensure themes were distinct, internally consistent and clearly defined (steps 4 and 5). The final phase involved selecting illustrative extracts and combining these with theme definitions to form an analytic narrative (step 6). To enhance transparency, each extract is labelled with a code that signals the participant's gender $(\mathrm{M}=$ male; $\mathrm{F}=$ female; $\mathrm{NB}=$ non-binary $)$, their participant number (1-82) and the type of legal relationship recognition they had $(\mathrm{CP}=$ civil partnership; $\mathrm{CPM}=$ civil partnership converted to a marriage; $\mathrm{M}=$ marriage)

\section{Findings}


Jowett, A. \& Peel, E. (2019). Reshaping relational scripts? Marriage and civil partnership proposals among same-gender couples. Psychology \& Sexuality http://dx.doi.org/10.1080/19419899.2019.1645726 Please cite published version. Two key themes were identified which captured initiation accounts of civil partnership or marriage: 1) Queer proposals $(n=32 ; 39 \%)$ and; 2) Jointly negotiated initiations $(n=23,28 \%)$. The remaining respondents $(n=27,33 \%)$ did not provide a clear, or any, account of how their civil partnership or marriage was initiated (e.g. 'Met through work, bought property together in 2007, CP in 2007', F52CP).

\section{Queer proposals}

Almost three fifths of respondents who provided an account of how their civil partnership or marriage was initiated described some form of 'proposal' in the form of one partner initiating or asking the other to marry them or to form a civil partnership. Such accounts were largely, although not exclusively, reported by those who had converted a civil partnership to a marriage or had married once it was legalised. Such accounts typically involved one or more elements of the traditional marriage proposal script while also deviating from the traditional script in key respects.

Few participants explicitly discussed how the decision was made as to which partner would propose, however a number of respondents suggested that there was some level of reciprocity within their proposals. For instance, one respondent suggested that after 'jokingly' proposing on many occasions, there was a mutual understanding that her partner would reciprocate with a formal proposal:

She proposed to me as I am the impatient one and over those 6 years before getting married I had proposed (somewhat jokingly) numerous times so I was always ready from the first day we kissed. She wasn't ready however so we left it to her to propose when she felt the time was right (F47M)

Similarly, another respondent whose initial proposal was not accepted, was later proposed to by her partner: I proposed but was not accepted and then she proposed to me two years later 
Jowett, A. \& Peel, E. (2019). Reshaping relational scripts? Marriage and civil partnership proposals among same-gender couples. Psychology \& Sexuality http://dx.doi.org/10.1080/19419899.2019.1645726

Please cite published version.

(F61M). In both cases, one partner had initially offered a proposal (either seriously or jokingly) and then it was left to the other partner to reciprocate. Even where there was no initial rejection, there were instances of reciprocal proposals: My partner proposed in 2005 and I returned the offer later that year! (F4CPM). Meanwhile another respondent suggested that the intention to propose was verbally reciprocated after the proposal: She still maintains that she would've proposed to me if I hadn't got in there first (F28CPM). As well as reciprocal proposals there were also multiple proposals. For example, one respondent described how their partner proposed prior to equal marriage legislation and then proposed again once it was legally possible to marry: My partner proposed in 2004 but we did not decide to get married until full marriage was legal. My partner proposed again on Xmas eve $2013(M 73 M)$.

Many of these accounts contained one or more of the scripted elements of the traditional marriage proposal (Schweingruber et al., 2004). One such element, was the element of 'surprise', with several respondents suggesting that the proposal was unexpected: I surprised my wife with the proposal, booking us a night away and a fancy restaurant $(F 33 C P M)$. In addition to being a surprise, the proposals were often described in ways that could be considered 'romantic'. Participants often suggested the proposal was marked as 'special' by virtue of its location or timing. Special locations included being proposed to on a beach, on a mountaintop or in a 'fancy' restaurant. Proposals were also described as being performed on a range of special occasions such as Christmas, New Year's Eve, Valentine's Day, a birthday, a relationship 'anniversary', during sunset or a combination of these: $M y$ (now) wife took me on holiday to Rome and proposed there on my birthday (F41CPM). As the first cohort of same-gender couples able to form civil partnerships or get married, for several respondents the timing of the proposal coincided with the passing of civil partnership 
Jowett, A. \& Peel, E. (2019). Reshaping relational scripts? Marriage and civil partnership proposals among same-gender couples. Psychology \& Sexuality http://dx.doi.org/10.1080/19419899.2019.1645726

Please cite published version. or equal marriage legislation itself, although in one case this was described as being a pragmatic rather than a purely romantic decision:

I proposed on the day that the Queen gave it [the Marriage (Same Sex Couples Act)] royal assent (I wanted to wait until then, as I didn't entirely trust Parliament not to suddenly abandon the bill etc) (M48M)

Only one participant explicitly referred to 'getting down on one knee', however the intention to enact the romantic script was ironically contrasted with the reality in practice:

I proposed on [omitted name] beach at sunset the week before we moved in together. It was a proper one-kneed "will you marry me?" proposal although being a bit nervous and waiting for optimum sunset I'd had us sitting on the pebbles for quite a while and my intended was moaning about being chilly by the time I got round to it! (F28CPM)

Another way that proposals conformed to the romantic script was to incorporate some form of artistic element such as a poem or a story:

I proposed through a story I wrote and had the illustrations drawn for the book. At the back of the book the pages were stuck together and the ring was stuck into the pages for her to find. I gave her the book as an early Christmas present at the top of [omitted name] Mountain after climbing it. She said yes! (F46CP)

Many of the respondents referred to presenting their partner with a ring or being presented with a ring: I bought her a ring and proposed very unceremoniously in Pizza Express $(F 23 C P)$. In one account of a somewhat awkwardly performed proposal, the presenting of a ring was itself enough to signal that a proposal was being performed:

I intended to propose two years after we met but I got nervous and just muttered something about having gotten her a ring and asked if she wanted it! She did and we got our civil partnership about half a year later. (F49CPM) 
Jowett, A. \& Peel, E. (2019). Reshaping relational scripts? Marriage and civil partnership proposals among same-gender couples. Psychology \& Sexuality http://dx.doi.org/10.1080/19419899.2019.1645726

Please cite published version.

One male respondent appeared to have found selecting a ring a particularly tricky task and chose instead to improvise with a confectionary prop to signify the missing element:

Having never bought a ring before, I hadn't realised that jewellery shops did not have an extensive stock of various ring designs in every size. As a result, I ended up proposing with a Haribo ring in order to manage to propose on the day the Bill passed. I did have to say I wasn't joking (M48M)

Accounts such as these reinforce the importance of presenting a ring for enacting a proposal for many couples.

Meanwhile another respondent described buying their rings together prior to the proposal being performed:

We bought our rings together on valentine's day- pretty much spontaneously while on a day trip to [omitted place name]. Then she kept them hidden and proposed properly in the place we originally met on the day after it became legal for same sex couples to get married (F47M)

In some respects, this echoes previous research which suggest that proposals are often, to some extent, prenegotiated (Schweingruber et al., 2004; Heaphy et al., 2013) although buying the rings together prior to proposing 'properly' may imply a further level of egalitarianism.

It should be noted that some proposals were described as being 'informal'. For example, one respondent described being proposed to online: Sally actually (informally) proposed to me on MSN Messenger (F66M); while another described proposing over the phone: There was no real proposal. I asked her on the phone if she wanted a CP (F13CP). It is interesting that this participant did not consider such a proposal to be a 'real' proposal, perhaps because it was missing many of the elements of the traditional script. Where less 
Jowett, A. \& Peel, E. (2019). Reshaping relational scripts? Marriage and civil partnership proposals among same-gender couples. Psychology \& Sexuality http://dx.doi.org/10.1080/19419899.2019.1645726 Please cite published version. traditional proposals were made, some respondents suggested that some form of confirmation was required that a proposal had indeed been intended:

My partner says I proposed in an oblique way before civil partnerships were introduced at a picnic with some straight friends. He said "does that mean what I think it means?" and I blushingly replied yes! (M70CP)

So, whilst all these proposals relate to and invoke symbolic elements of the conventional cultural script to a degree, they also entail adaptation to the particulars of social context (Simon \& Gagnon, 1986). This social context includes both the particulars of each couple's relationship but also the wider political context of the shifting legal landscape with regards to the recognition of same-gender relationships in the UK.

\section{Jointly negotiated initiations}

In addition to less traditional (and 'queer') forms of proposals, over two fifths of those who provided an account of their civil partnership/marriage initiation indicated that there was no proposal at all. Such accounts were reported predominantly, although not exclusively, by those who had formed a civil partnership and had chosen not to convert to a marriage. Such accounts departed more radically from the proposal script and could be thought of as an alternative script characterised by (1) discussion and mutual agreement; (2) a process of negotiation that unfolds over time and; (3) foregrounding practical considerations.

Responses falling within this theme described the decision to marry or enter a civil partnership as being a joint decision arrived at through discussion: Neither of us proposed, it was something we discussed (F9CP). This kind of account often suggested that the decision to formalise the relationship was one of mutual agreement rather than one partner playing the role of initiator and the other taking a reactive role: We mutually agreed to formalise our 
Jowett, A. \& Peel, E. (2019). Reshaping relational scripts? Marriage and civil partnership proposals among same-gender couples. Psychology \& Sexuality http://dx.doi.org/10.1080/19419899.2019.1645726

Please cite published version. relationship and enter civil partnership (F38CPM). The word 'we' was central to such accounts, implying a more egalitarian form of decision making.

For many participants in the study, some of whom had been together for a long time prior to civil partnership or marriage being available for same-gender couples, the decision to legally formalise their relationship did not signal a new phase of the relationship. For some participants, their commitment had already been signalled through the merging of finances or jointly owning property:

We discussed the 'concept' of marriage, both knew we wanted to make a lifelong commitment to each other and both said that if the option was there we would want to be married. It's an interesting concept how gay couples approached the subject in the absence of a formal union or the ability to broach the subject by the means of a proposal. By the time civil partnerships were introduced in 2005 many gay couples had already made a personal lifelong commitment to each other. We bought a property together in 2007 and this emotional and financial commitment seemed significant for us. It also seemed to be a signal of commitment to our families who struggled at the time to accept and discuss our relationship. A short time after, we entered into a civil partnership. There was never a formal proposal (asking someone to be your civil partner doesn't sound like the most romantic gesture) (F29CP).

We lived together for 7 years before getting married in April 2014. There was no formal proposal, although we had talked about getting married fairly often during our relationship, and attended several friends' civil partnerships. It just felt as if it was the right time for us. Deciding to jointly pay for a new dishwasher seemed to be the catalyst for making the decision to actually get married rather than just talk about it! (F51M) 
Jowett, A. \& Peel, E. (2019). Reshaping relational scripts? Marriage and civil partnership proposals among same-gender couples. Psychology \& Sexuality http://dx.doi.org/10.1080/19419899.2019.1645726

Please cite published version.

That there was 'no' 'formal proposal' - implicitly akin to the conventional script - is made explicit in these accounts, which emphasise joint commitment. Some explicitly noted the unromantic nature of their decision to legally formalise their relationship:

We started discussing getting married approximately one year after we first met and decided that we should get engaged as we wanted to get married. It was perhaps not the most romantic way to get engaged but it worked for us. (F53M)

Indeed, in contrast to the accounts of proposals taking place in special or romantic locations, these joint decisions were more often described as taking place in mundane (not obviously romantic) settings: Our proposal was a discussion in the car (M54CPM).

It is clear from some of these accounts that a discussion was required as there was not an assumption that marriage was inevitable or desirable. Furthermore, some couples who were initially critical of the idea of marriage, changed their mind over time through discussions as a couple:

One summer, on a road trip, we started talking about how our time and money was constantly spent on straight weddings and critically asking why would anyone ever marry. It became clear over the course of the road trip that there were reasons to formally partner up that were compelling to us personally. Neither of us proposed but by the end of the trip it was clear that we would have a ceremony (NB80CPM)

We started out initially both not being especially keen to have a civil partnership, but as time went on we decided that it would be very special and meaningful to formalise our relationship in this way. There was no proposal as such and we decided that the idea of engagement didn't really appeal to us and so didn't bother with engagement 
Jowett, A. \& Peel, E. (2019). Reshaping relational scripts? Marriage and civil partnership proposals among same-gender couples. Psychology \& Sexuality http://dx.doi.org/10.1080/19419899.2019.1645726 Please cite published version. rings. We thought that it was well-meaning but slightly odd when we received an engagement card from a friend - those just weren't our frames of reference (F76CP)

In this last extract, not only was there 'no proposal as such', indicated by the lack of scripted elements such as the absence of engagement rings, marriage is reported as not being their 'frame of reference'. Not all participants treated civil partnership as synonymous with marriage. For some, particularly those who had chosen not to convert their civil partnership to a marriage or who had chosen a civil partnership after marriage had become an option, civil partnership represented a modern alternative free from the connotations and expectations of marriage (Jowett \& Peel, 2017). By not taking marriage as their frame of reference, such couples may have felt free to ignore the conventions of the traditional marriage proposal or actively resisted them.

For a number of participants, deciding to have a civil partnership was described in terms of legal protections for the couple rather than in terms of romantic or symbolic significance:

We had been together for about a year when I realised that our children would be very vulnerable if we didn't organise some legal recognition of our relationship and one of us died or became incapacitated (we have three children from previous relationships). It was unromantic in the extreme because it was primarily motivated by trying to prevent my partner's abusive ex getting residence of her children if she died (step parents have stronger rights in relation to children than informal partners) and in relation to inheritance tax if I died (my partner and children wouldn't be able to afford the tax bill to keep their home unless we got married or had a CP). (F15CP) For these participants legal recognition of their relationship was more about securing legal rights, breaking with the idea that romantic love is the only authentic motivation for 
Jowett, A. \& Peel, E. (2019). Reshaping relational scripts? Marriage and civil partnership proposals among same-gender couples. Psychology \& Sexuality http://dx.doi.org/10.1080/19419899.2019.1645726 Please cite published version. formalising a relationship (Heaphy, 2017). This participant also expressed in response to a later question that she preferred civil partnership to marriage as it 'doesn't carry the same societal baggage' and that 'just because you can fit your relationship into a heteronormative box now doesn't mean that feels like the right box for us'. For such respondents, the absence of a traditional proposal may have been part of a wider rejection of heteronormativity.

For many of the participants, civil partnership and/or equal marriage legislation came into being during the lifetime of their relationship. As such, the public debate about civil partnership and equal marriage may have instigated discussions among same-gender couples (see also Peel \& Harding, 2004):

During the two years leading up to cohabiting we joked and then spoke more seriously about a civil partnership (equal marriage hadn't happened at this point). Eventually we made a consensus decision to do it for the reasons given below. We also wrote wills and took out power of attorney etc in preparation for old age and our demise. $(F 82 C P)$

In such accounts, the decision to enter a civil partnership was not presented as an 'event' but rather as a process that unfolds over time. It is also presented as a decision which the couple reach by 'consensus' rather than being initiated by one party. Another element of the above extract, which was common among accounts where there was no proposal, is the construction of it being a practical decision with a view to future security, more comparable to deciding to write a will:

We saw our civil partnership as a functional way to protect ourselves under the law, rather than a marriage. We didn't feel it was a marriage so there was no proposing (F42CP) 
Jowett, A. \& Peel, E. (2019). Reshaping relational scripts? Marriage and civil partnership proposals among same-gender couples. Psychology \& Sexuality http://dx.doi.org/10.1080/19419899.2019.1645726 Please cite published version. The salience of the protections afforded by legally formalising a relationship was in one case heightened due to experiencing health issues and poor relationships with the partner's family of origin:

One of us has a very poor relationship with family. We ensured when the house was set up that it was done in a way that excluded any possible claim from them. When he was taken ill in 2003 it was clear that we needed other protections in terms of having a say over health care. After a successful operation in 2005 we decided a civil partnership would be a good idea (M75CP)

So, in sum, all accounts within this theme depart from the heteronormative script and instead present their marriage or civil partnership initiation as a more egalitarian and negotiated form of decision making. Once again, the initiation of civil partnership and marriage are described as being situated within the couple's personal circumstances (e.g. poor health, legal precarity) and the wider heteronormative social context.

\section{Discussion}

Our study has identified two ways in which same-gender couples describe the initiation of their civil partnership or marriage. The first involved one partner initiating the decision by asking the other to marry or form a civil partnership (i.e. there was a 'proposal'). Many of these accounts adopted at least some elements of the traditional marriage proposal script identified by Schweingruber et al. (2004) such as surprising their partner, proposing at a romantic time or place, presenting a ring or getting down on one knee. None of the participants reported asking their partner's father for permission (although we cannot say for certain that this did not occur). Others described a more informal proposal whereby one partner asked the other in a less romantic manner as well as in a more mundane setting. So while many same-gender couples did adopt a form of the 'marriage' proposal, participants 
Jowett, A. \& Peel, E. (2019). Reshaping relational scripts? Marriage and civil partnership proposals among same-gender couples. Psychology \& Sexuality http://dx.doi.org/10.1080/19419899.2019.1645726

Please cite published version. also expressed a degree of ambivalence towards the convention (Heaphy et al., 2015) and displayed what Heaphy (2017) has referred to as a 'reflexive investment in marriage and family conventions' (p. 3).

The second type of initiation was in the form of a jointly negotiated decision arrived at through discussion. These accounts did not indicate that the legal formalising of their relationship was initiated by one partner asking the other but rather through discussion and mutual agreement. These accounts sometimes noted the 'unromantic' nature of their decision, implicitly in contrast to the romantic script they were departing from. As Peel and Harding (2004) note, any formalising of same-gender relationships is always viewed in reference to the framework of heterosexual marriage and that even resistance to such a framework involves an acknowledgement of it. In contrast to the romantic script, some participants also described formalising their relationship for pragmatic purposes (e.g., for future security). Additionally, unlike the 'proposal', accounts of joint decisions were typically not described as an event but rather as a process that unfolded over time.

The fact that accounts of proposals were more often provided by those who had married (or converted a civil partnership to a marriage) while those who described a joint decision were typically those in a civil partnership may indicate that these couples view the legal formalisation of their relationships differently. Many of our participants who entered a civil partnership and subsequently converted to a marriage, had always viewed their civil partnership as a marriage-like framework. Meanwhile some who had chosen not to convert to marriage did not see their civil partnership as mimicking the heteronormative model (see also Jowett \& Peel, 2017). For those who viewed civil partnership as a marriage, the traditional conventions of marriage (such as the proposal) may have been considered relevant even if they required some adapting in the absence of clear gender roles. Meanwhile, those who do not take marriage as their frame of reference may be less likely to adopt such conventions. 
Jowett, A. \& Peel, E. (2019). Reshaping relational scripts? Marriage and civil partnership proposals among same-gender couples. Psychology \& Sexuality http://dx.doi.org/10.1080/19419899.2019.1645726

Please cite published version.

This study provides an important contribution to our understanding of same-gender

relationships and marriage. We have identified ways in which same-gender couples adopt and modify the cultural script for a marriage proposal or, in some cases, replace it with negotiated decision making, particularly when initiating a civil partnership. As such, this analysis also has significant implications for script theory. Common criticisms of sexual script theory are that it often fails to explain how scripts emerge, and that research has tended to focus on relational scripts among heterosexuals (Wiederman, 2015).

We argue that alternative scripts are brought about by the absence of a clear set of rules about what is normative among same-gender couples; what Brown (1989) refers to as 'normative creativity'. Focusing on scripts among same-gender couples themselves, as an object of study, is therefore interesting for understanding how scripts can develop. We contend that normative creativity also emerges in the context of newly introduced, nonnormative institutions such as civil partnership. As a new social institution, there are no clear and established norms around civil partnership, which allows for greater creativity both in how they are initiated and enacted (Clarke et al., 2013) - notwithstanding the potential for alternative practices to be enacted within mixed-gender proposals. Established relational norms, in the case of mixed-gender marriage proposals are by definition a framework rather than a straight jacket.

While consistent with previous research on same-gender relationships in a number of ways, our findings break new ground with regards to what we know about how same-gender couples initiate formalising their relationships in the context of marriage equality. In addition, this study identifies an alternative script, whereby the proposal is replaced by negotiated discussion and mutual agreement. Alternative relationship scripts can emerge within lesbian, gay and queer cultures and are shaped by values within these subcultures (Rose, 1996). The emphasis on joint decision-making and accounts of reciprocal proposals aligns with the 
Jowett, A. \& Peel, E. (2019). Reshaping relational scripts? Marriage and civil partnership proposals among same-gender couples. Psychology \& Sexuality http://dx.doi.org/10.1080/19419899.2019.1645726

Please cite published version. broader literature on same-gender relationships which suggests that freedom from heteronormatively gendered roles allows for more egalitarian, reciprocal and mutually negotiated ways of doing relationships (Dunne, 1997; Rose \& Zand, 2002).

However, such apparent differences across couples may mask underlying similarities. Previous research with both mixed-gender and same-gender couples has suggested that the decision to formalise a relationship is often 'prenegotiated' prior to the proposal taking place (Heaphy et al., 2015; Lamont, 2013; Sassler \& Miller, 2011; Schweingruber et al., 2004). In such cases, it could be said that the decision is reached jointly over time, often through discussion, prior to the proposal in a way similar to those who describe 'the proposal' being absent in our data. Similarly, accounts of reaching a decision through mutual consensus may mask underlying power differences or instances of one partner initiating such discussions. As Heaphy et al. (2015) suggest: 'it would be naïve to think that the absence of obvious gender differences meant that the interactions and decision-making within couple relationships are power free' (p. 95). Furthermore, mixed-gender relationships may be becoming more egalitarian than suggested from the limited evidence on marriage proposals which is itself historically and geographically situated.

We would also view (accounts of) proposals as functioning to communicate something about their relationship to the wider world. As such, conforming to such conventions may be done in a strategic way. Just like other marriage conventions, such as wedding ceremonies, proposals may function as a performative claim to normality and legitimacy (Heaphy, 2017). Meanwhile accounts which claim the decision was jointly initiated may be performatively resisting heteronormativity and designed to construct their relationship as one based in equality (Jowett, 2018). In other words, participants may construct accounts to portray their relationships as normal or egalitarian rather than these accounts reflecting these qualities in their relationship. 
Jowett, A. \& Peel, E. (2019). Reshaping relational scripts? Marriage and civil partnership proposals among same-gender couples. Psychology \& Sexuality http://dx.doi.org/10.1080/19419899.2019.1645726 Please cite published version.

Some limitations of the study should be noted. The method of data collection meant that we are limited to the accounts volunteered in the survey without an opportunity to probe further or ask for clarification. Our sample also consisted predominantly of highly educated, professional women, and as such the findings may not be representative of same-gender couples more broadly. In addition, our data captures a snapshot at a particular point in history when marriage is a new institution for same-gender couples.

Future research may wish to use interviews to examine further some of the findings highlighted here. For example, it is not clear from our data what determines which partner proposes, other than a willingness or desire to do so. There was a suggestion by several participants that the partner who was most eager to formalise their relationship made this known and then waited for the other partner to reciprocate in the form of a proposal but this could be examined further. Research could also examine gender differences between malemale and female-female marriage initiations or in relation to butch-femme identities, particularly given that the agentic elements of proposals are traditionally performed by men. Future research could also examine how these practices evolve over time. As marriage among same-gender couples become more established, it is possible that the traditional conventions of marriage may become more normalised among lesbians and gay men. Indeed, Heaphy (2015) claims that a younger generation of same-gender couples already appear to aspire to 'ordinary' marriage. Furthermore, when civil partnerships are extended to mixedgender couples, research could examine whether they adopt marriage conventions, such as the 'proposal' or if new scripts take its place.

\section{Acknowledgements}


Jowett, A. \& Peel, E. (2019). Reshaping relational scripts? Marriage and civil partnership proposals among same-gender couples. Psychology \& Sexuality http://dx.doi.org/10.1080/19419899.2019.1645726

Please cite published version.

The authors would like to thank the participants for taking time to complete the survey and anyone who helped to share the link to the survey, in particular DIVA magazine. Thanks to Sarah Holloway for her helpful comments on an earlier version.

\section{References}

Baker, M., \& Elizabeth, V. (2013). 'Did you just ask me to marry you?': The gendered nature of heterosexual relationship progressions. Women's Studies Journal, 27(2), 32-43.

Barker, N., \& Monk, D. (2015). From civil partnership to same-sex marriage: A decade in British legal history. In N. Barker \& D. Monk (Eds.), From civil partnership to samesex marriage: Interdisciplinary reflections (pp. 1-26). Abingdon: Routledge.

BBC News (2018). Civil partnership Bill clears Commons. Available from: https://www.bbc.co.uk/news/uk-politics-45994406 [accessed on 08 November 2018]

Brown, L. S. (1989). New voices, new visions: Toward a lesbian/gay paradigm for psychology. Psychology of Women Quarterly, 13(4), 445-458.

Clarke, V., Braun, V., \& Hayfield, N. (2015). Thematic analysis. In J. A. Smith (Ed.), Qualitative Psychology: A practical guide to research methods ( $3^{\text {rd }}$ ed., pp. 222-248). London: Sage.

Clarke V, Burgoyne, C., \& Burns, M. (2005). For love or money? Comparing lesbian and gay and heterosexual relationships. The Psychologist 18: 356-358.

Clarke, V., Burgoyne, C., \& Burns, M. (2006). Just a piece of paper? A qualitative exploration of same-sex couples' multiple conceptions of civil partnership and marriage. Lesbian \& Gay Psychology Review, 7(2), 141-161.

Clarke, V., Burgoyne, C., \& Burns, M. (2013). Unscripted and improvised: Public and private celebrations of same-sex relationships. Journal of GLBT Family Studies, 9(4), 393-418. 
Jowett, A. \& Peel, E. (2019). Reshaping relational scripts? Marriage and civil partnership proposals among same-gender couples. Psychology \& Sexuality http://dx.doi.org/10.1080/19419899.2019.1645726

Please cite published version.

Dunne, G. A. (1997). Lesbian lifestyles: Women's work and the politics of sexuality. University of Toronto Press.

Ellis, S.J., Riggs, D.W. \& Peel, E. (2020). Lesbian, Gay, Bisexual, Trans, Intersex \& Queer Psychology: An introduction. (2 ${ }^{\text {nd }}$ Ed.) Cambridge: Cambridge University Press.

Gagnon, J.H., \& Simon, W. (1973). Sexual conduct: The social sources of human sexuality. Chicago, IL: Aldine.

Government Equalities Office (2018). The Future Operation of Civil Partnership: Gathering Further Information. Available from:

https://assets.publishing.service.gov.uk/government/uploads/system/uploads/attachme

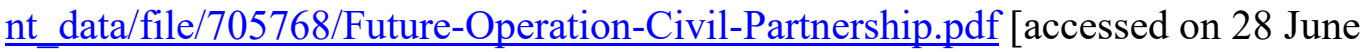
2018]

Harding, R. (2008). Recognizing (and resisting) regulation: Attitudes to the introduction of civil partnership. Sexualities, 11(6), 740-760.

Harding, R., \& Peel, E. (2006). We do? International perspectives on equality, legality and same-sex relationships. Lesbian \& Gay Psychology Review, 7(2), 123-140.

Heaphy, B. (2015). Civil partnerships and ordinary marriage. In N. Barker \& D. Monk (Eds.), From civil partnership to same-sex marriage: Interdisciplinary reflections (pp. 115131). Abingdon: Routledge.

Heaphy, B. (2017). Reflexive convention: civil partnership, marriage and family. The British Journal of Sociology. doi:10.1111/1468-4446.12308

Heaphy, B., Smart, C., \& Einarsdottir, A. (2013). Same Sex Marriages: New generations, new relationships. Basingstoke: Palgrave Macmillan.

Jowett, A. (2018). Gendered accounts of managing diabetes in same-sex relationships: A discursive analysis of partner support. Health, 22(2), 147-164.

Jowett, A. \& Peel, E. (2010). Seismic cultural change?: British media representations of 
Jowett, A. \& Peel, E. (2019). Reshaping relational scripts? Marriage and civil partnership proposals among same-gender couples. Psychology \& Sexuality http://dx.doi.org/10.1080/19419899.2019.1645726

Please cite published version. same-sex marriage. Women's Studies International Forum, 33, 206-214.

Jowett, A., \& Peel, E. (2017). 'A question of equality and choice': same-sex couples' attitudes towards civil partnership after the introduction of same-sex marriage. Psychology \& Sexuality, 8(1-2), 69-80.

Kimport, K. (2012). Remaking the white wedding? Same-sex wedding photographs' challenge to symbolic heteronormativity. Gender \& Society, 26(6), 874-899.

Klinkenberg, D., \& Rose, S. (1994). Dating scripts of gay men and lesbians. Journal of Homosexuality, 26(4), 23-35.

Kurdek, L. A. (2007). The allocation of household labor by partners in gay and lesbian couples. Journal of Family Issues, 28(1), 132-148.

Lewin, E. (1998). Recognizing ourselves: Ceremonies of lesbian and gay commitment. Columbia University Press.

Lukes, C. A., \& Land, H. (1990). Biculturality and homosexuality. Social work, 35(2), 155161.

Patterson, C. J., \& Farr, R. H. (2017). What shall we call ourselves? Last names among lesbian, gay, and heterosexual couples and their adopted children. Journal of GLBT Family Studies, 13(2), 97-113.

Peel, E., \& Harding, R. (2004). Civil partnerships: A new couple's conversation. Feminism \& Psychology, 14(1), 41-46.

Reczek, C., Elliott, S., \& Umberson, D. (2009). Commitment without marriage: Union formation among long-term same-sex couples. Journal of Family Issues, 30(6), 738756.

Rose, S. (1996). Lesbian and gay love scripts. In E. D. Rothblum \& L. A. Bond (Eds.), Preventing heterosexism and homophobia (pp. 151-173). Thousand Oaks, CA: Sage. Rose, S., \& Frieze, I. H. (1993). Young singles' contemporary dating scripts. Sex Roles, 28(9- 
Jowett, A. \& Peel, E. (2019). Reshaping relational scripts? Marriage and civil partnership proposals among same-gender couples. Psychology \& Sexuality http://dx.doi.org/10.1080/19419899.2019.1645726

10), 499-509.

Please cite published version.

Rose, S. M., \& Zand, D. (2002). Lesbian dating and courtship from young adulthood to midlife. Journal of Lesbian Studies, 6(1), 85-109.

Sassler, S., \& Miller, A. J. (2011). Waiting to be asked: Gender, power, and relationship progression among cohabiting couples. Journal of Family Issues, 32(4), 482-506.

Schweingruber, D., Anahita, S., \& Berns, N. (2004). "Popping the question" when the answer is known: The engagement proposal as performance. Sociological Focus, 37(2), 143161.

Schweingruber, D., Cast, A. D., \& Anahita, S. (2008). “A story and a ring”: Audience judgments about engagement proposals. Sex Roles, 58(3-4), 165-178.

Schweingruber, D., \& Scheuble, L. K., \& Berns, N. (2001). The happiest day of whose life? Gender differences in attitudes toward engagements. In Annual Meeting of the Midwest Sociological Society, St. Louis, MO.

Simon, W., \& Gagnon, J. H. (1986). Sexual scripts: Permanence and change. Archives of Sexual Behavior, 15(2), 97-120.

Smart, C. (2008). 'Can I be bridesmaid?' Combining the personal and political in same-sex weddings. Sexualities, 11(6), 761-776.

Suter, E. A., \& Oswald, R. F. (2003). Do lesbians change their last names in the context of a committed relationship? Journal of Lesbian Studies, 7(2), 71-83.

Terry, G. \& Braun. V. (2017). Short but often sweet: the surprising potential of qualitative survey methods. In V. Braun \& V. Clarke (eds.) Collecting Qualitative Data: A practical guide to textual, media and virtual techniques. (pp. 15-44). Cambridge: Cambridge University Press.

Wiederman, M.F. (2015). Sexual script theory: Past, present, and future. In J. DeLamater \& R. Plante (eds) Handbook of the Sociology of Sexualities. (pp.7-22) Cham: Springer. 
Jowett, A. \& Peel, E. (2019). Reshaping relational scripts? Marriage and civil partnership proposals among same-gender couples. Psychology \& Sexuality http://dx.doi.org/10.1080/19419899.2019.1645726

Please cite published version.

Willig, C. (1999). Beyond appearances: A critical realist approach to social constructionism.

In D. J. Nightingale \& J. Cromby (Eds.), Social constructionist psychology: A critical analysis of theory and practice (pp. 37-51). Buckingham: Open University Press. 